\title{
Elevated creatine kinase activity in primary hepatocellular
} carcinoma

\author{
Georg Meffert, Frank N Gellerich, Raimund Margreiter and Markus Wyss*
}

Address: Department of General and Transplant Surgery, University Hospital, Anichstrasse 35, A-6020 Innsbruck, Austria

Email: Georg Meffert - GMeffert@gmx.ch; Frank N Gellerich - frank.gellerich@keyneurotek.de;

Raimund Margreiter - Raimund.Margreiter@uibk.ac.at; Markus Wyss* - markus.wyss@dsm.com

* Corresponding author

Published: 05 March 2005

BMC Gastroenterology 2005, 5:9 doi:10.1 186/147/-230X-5-9

This article is available from: http://www.biomedcentral.com/l47/-230X/5/9

(c) 2005 Meffert et al; licensee BioMed Central Ltd.

This is an Open Access article distributed under the terms of the Creative Commons Attribution License (http://creativecommons.org/licenses/by/2.0), which permits unrestricted use, distribution, and reproduction in any medium, provided the original work is properly cited.
Received: 12 November 2004

Accepted: 05 March 2005

\begin{abstract}
Background: Inconsistent findings have been reported on the occurrence and relevance of creatine kinase $(\mathrm{CK})$ isoenzymes in mammalian liver cells. Part of this confusion might be due to induction of $\mathrm{CK}$ expression during metabolic and energetic stress.

Methods: The specific activities and isoenzyme patterns of CK and adenylate kinase (AdK) were analysed in pathological liver tissue of patients undergoing orthotopic liver transplantation.

Results: The brain-type, cytosolic BB-CK isoenzyme was detected in all liver specimens analysed. Conversely, CK activity was strongly increased and a mitochondrial CK (Mi-CK) isoenzyme was detected only in tissue samples of two primary hepatocellular carcinomas (HCCs).

Conclusion: The findings do not support significant expression of CK in normal liver and most liver pathologies. Instead, many of the previous misconceptions in this field can be explained by interference from AdK isoenzymes. Moreover, the data suggest a possible interplay between p53 mutations, HCC, CK expression, and the growth-inhibitory effects of cyclocreatine in HCC. These results, if confirmed, could provide important hints at improved therapies and cures for HCC.
\end{abstract}

\section{Background}

Creatine kinase (CK) isoenzymes catalyse the reversible transfer of the phosphate group of phosphocreatine (PCr) to ADP, to yield ATP and creatine (Cr). The $\mathrm{CK} / \mathrm{PCr} / \mathrm{Cr}$ system is present primarily in tissues with high and fluctuating energy demands such as brain, heart and skeletal muscle, and serves as a temporal and spatial "energy buffer" that helps to maintain a high intracellular phosphorylation potential in situations of increased metabolic demand (for reviews, see $[1,2]$ ).

In mammals, $\mathrm{Cr}$ can be taken up by the intestine from the food, or can be synthesized de novo. The liver is the main site of Cr production in the body (see [2]). After its synthesis, Cr is transported through the blood and is taken up by Cr-containing tissues via a specific $\mathrm{Cr}$ transporter. Whereas the importance of the liver in $\mathrm{Cr}$ biosynthesis is undisputed, some confusion still exists on the CK activity and $\mathrm{PCr}$ content in this organ. The majority of findings suggest no or minute levels of $\mathrm{CK}$ and $\mathrm{PCr}$ in liver tissue and, in particular, in hepatocytes (e.g., [3-6]). Other studies that used more sensitive experimental approaches provided evidence for low levels of $\mathrm{PCr}$ and $\mathrm{CK}$, specifically localized in sinusoidal endothelial cells ([7-9]; see also [10]). Finally, in a few cases, more extreme findings were made: unusually high levels of CK activity were measured 
in liver tissue by Shatton et al. [11], Goullé et al. [12], and Wali \& Makinde [13].

The majority of studies indicated that the low levels of CK activity in liver are due solely to the brain-type cytosolic CK (BB-CK) isoenzyme. On the other hand, besides BBCK which was suggested to be present in endothelial and Kupffer cells, Vaubourdolle et al. [14] also provided evidence for the presence of the muscle-type cytosolic (MM$\mathrm{CK}$ ) isoenzyme in Ito cells, and for mitochondrial CK (MiCK) in hepatocytes. Similarly, Kanemitsu et al. [15] purified Mi-CK from normal human liver, which would imply significant amounts of this isoenzyme in liver tissue. Finally, increases in serum CK activity were frequently observed in cases of severe liver disease, with the most obvious source of CK being the pathological liver tissue itself [16-18].

In a number of studies reporting significant levels of CK activity in liver, interference by adenylate kinase (AdK) isoenzymes in the CK activity assays [19-21] is very likely (e.g., [13]), or can at least not be excluded, thus questioning the validity of these studies. Another possible cause for inconsistent findings might be compensatory up-regulation of CK expression in pathological liver tissue. Two lines of evidence that favour this hypothesis are: (i) partially hepatectomized rat liver was reported to show an increase in BB-CK activity (see [22]); and (ii) overexpression of CK isoenzymes in the liver of transgenic mice was shown to stabilize energy metabolism under low-oxygen stress and after a metabolic challenge $[23,24]$, to accelerate regeneration of liver mass following major hepatectomy $[10,25]$, and to increase endotoxin tolerance $[5,26]$.

Because of these conflicting data, the goal of the present study was to analyse in detail the CK and AdK activities in pathological liver tissue of patients undergoing orthotopic liver transplantation.

\section{Methods}

\section{Liver samples}

The present project was approved by the ethics commission of the University of Innsbruck. In total, 25 liver samples were analysed. Twenty-three samples were obtained from 18 explanted organs of liver transplant recipients, one sample was obtained at autopsy (no. 1), and the last sample was from a normal rat liver. According to pathomorphological criteria, the 25 samples can be divided into 5 groups: (1) Nine samples of cirrhotic liver tissue (nos. 5 , $7,11,13,17-19,23,24: 4$ due to hepatitis B or C virus infection, 3 due to primary or secondary biliary cirrhosis, 1 due to chronic alcohol abuse, and 1 due to vena hepatica occlusion); (2) six samples of neoplastic tissue (nos. 4, 9, 14, 15, 20, 21: 3 cholangiocellular carcinomas, 2 primary hepatocellular carcinomas, and 1 liver metastasis of a malignant melanoma); (3) three samples of necrotizing liver tissue due to acute or subacute organ rejection (nos. $2,6,22)$; (4) five samples of macroscopically normal liver parenchymal tissue (nos. 3, 8, 10, 16, 25) surrounding focal liver pathologies (i.e., 2 primary HCCs [samples 4 and 9]; metastasis of malignant melanoma [sample 15]; vena hepatica occlusion [sample 24]); (5) two samples originating from a normal rat liver (no. 12) and from a patient with steatosis hepatis (no. 1).

\section{Preparation of homogenate, cytosolic and mitochondrial fractions of human and rat liver}

All steps were performed on ice or at $4{ }^{\circ} \mathrm{C}$. Approximately $5 \mathrm{~g}$ of liver tissue was homogenized in $45 \mathrm{ml}$ buffer A ( 250 $\mathrm{mM}$ sucrose, $5 \mathrm{mM}$ HEPES, $0.5 \mathrm{mM}$ EGTA, $\mathrm{pH}$ 7.4). The homogenate was subjected to centrifugation for $5 \mathrm{~min}$ at $800 \mathrm{~g}$. The pellet was discarded, and the supernatant centrifuged for $4 \mathrm{~min}$ at $5,100 \mathrm{~g}$ (centrifugation $\mathrm{C} 2$ ). The supernatant of $\mathrm{C} 2$ was further clarified by centrifugation for $12 \mathrm{~min}$ at $12,300 \mathrm{~g}$, thus yielding the cytosolic fraction. The pellet of $\mathrm{C} 2$ was resuspended in $10 \mathrm{ml}$ buffer $\mathrm{A}$, followed by centrifugation for $2 \mathrm{~min}$ at $12,300 \mathrm{~g}$ (C3). After resuspension of the $\mathrm{C} 3$ pellet in $10 \mathrm{ml}$ buffer $\mathrm{A}$ and centrifugation for a further $10 \mathrm{~min}$ at $12,300 \mathrm{~g}$, the sediment was resuspended in $4 \mathrm{ml}$ buffer $\mathrm{A}$, thus yielding the mitochondrial fraction. One-ml aliquots of the different fractions were immediately frozen in liquid nitrogen and stored at $-80^{\circ} \mathrm{C}$ until analysis.

\section{Measurements of CK and AdK activity}

For CK and AdK activity measurements, the following assay medium was used: $110 \mathrm{mM}$ imidazole, $\mathrm{pH}$ 6.7, 20.5 $\mathrm{mM}$ glucose, $11 \mathrm{mM} \mathrm{Mg}$-acetate, $2.05 \mathrm{mM}$ EDTA $\cdot \mathrm{Na}_{2}, 2.1$ mM ADP, $2.1 \mathrm{mM}$ NADP, $21 \mathrm{mM} \mathrm{N}$-acetylcysteine, $9 \mathrm{U} /$ $\mathrm{ml}$ of hexokinase, and $5.8 \mathrm{U} / \mathrm{ml}$ of glucose-6-phosphate dehydrogenase (both from Sigma). Enzymatic activity was measured at $25^{\circ} \mathrm{C}$ as an increase in NADPH absorbance at $340 \mathrm{~nm}$. For AdK, three separate measurements were made for each sample in the same assay medium. For CK measurements, $5.1 \mathrm{mM}$ AMP was added to the assay medium to inhibit AdK activity. For each sample, three measurements with $10.3 \mathrm{mM} \mathrm{PCr}$ and three measurements without PCr (blank measuring residual AdK activity after inhibition with AMP) were made, and the CK activity was calculated as the difference of the respective means. All values in this paper represent specific activities per mg of homogenate, cytosolic or mitochondrial protein. Protein amounts were measured according to the method of Bradford [27] with bovine serum albumin as standard.

\section{Cellulose polyacetate electrophoresis (CPE)}

CPE was performed at room temperature for $90 \mathrm{~min}$ at a constant voltage of $150 \mathrm{~V}$, but otherwise as described previously [28]. CK and AdK isoenzyme bands were 
visualized at $37^{\circ} \mathrm{C}$ with an overlay gel technique in a reaction protocol similar to the one described above for the measurement of enzymatic activity. NADPH was reacted with nitrobluetetrazolium in the presence of phenazine methosulfate to yield formazan. For visualization of CK bands, AMP was added to the overlay gel to inhibit AdK activity. Since AMP alone may not be sufficient to inhibit all AdK activity [21], two identical cellulose polyacetate strips were run; one was developed with $\mathrm{PCr}$ in the overlay gel, whereas for the other, PCr was omitted from the overlay gel (blank).

\section{Results}

CK and AdK activities were measured in total homogenate (Fig. 1), cytosolic and mitochondrial fractions (data not shown) obtained by differential centrifugation from 25 normal and pathological liver samples. Highest CK activities were observed in the two primary HCCs analysed (liver samples no. 4 and 9), with specific CK activities in the homogenate of 0.36 and $0.21 \mathrm{U} \cdot(\mathrm{mg} \text { protein })^{-1}$, respectively. In most other liver samples, the specific CK activities in the homogenate were below $0.05 \mathrm{U} \cdot$ (mg protein) ${ }^{-1}$. Whereas enzymatic activity measurements revealed low, but consistent $\mathrm{CK}$ activity in many of the cytosolic fractions, no CK activity was detected in the mitochondrial fractions, except for HCC sample no. 9 with a specific CK activity of approx. $0.1 \mathrm{U} \cdot(\mathrm{mg}$ protein)${ }^{1}$ (due to limited sample size, subcellular fractionation was not feasible for HCC sample no. 4). These findings were corroborated qualitatively by isoenzyme electrophoresis on cellulose polyacetate strips. Visualization of the different $\mathrm{CK}$ isoenzymes by an overlay gel technique revealed that the brain-type cytosolic BB-CK isoenzyme was present in all liver samples. Conversely, bands for the dimeric and octameric forms of Mi-CK were only observed in the two primary HCC samples (nos. 4 and 9; Fig. 2).

The CK/AdK activity ratio in the homogenate was 1.4 and 2.6 for the two primary HCCs (liver samples no. 4 and 9, respectively), 0.5 for liver sample no. 5 (secondary biliary cirrhosis), and $<0.2$ for all other liver samples. Similar findings were made for the cytosolic and mitochondrial fractions, with CK/AdK activity ratios of $<0.3$ for the cytosolic fraction and $<0.05$ for the mitochondrial fraction. For HCC sample no. 9, however, these ratios were significantly higher: 4.8 (cytosolic fraction) and 0.33 (mitochondrial fraction).

\section{Discussion}

CK is an enzyme still widely analysed in clinical diagnostics. Although a wealth of CK measurements have been reported in the scientific literature, there still exist inconsistency and incomplete knowledge on such an apparently simple question as the CK (isoenzyme) content of mammalian liver in both health and disease. In the present study, we detected the presence of BB-CK in all liver samples analysed by using CK activity measurements and cellulose polyacetate electrophoresis. However, in the normal and most pathological liver samples that we analysed, the specific CK activity was very low $(<0.05 \mathrm{U} \cdot[\mathrm{mg}$ protein] ${ }^{-1}$ ), levels which are comparable with or lower than data reported for rat and human liver $[29,30]$, but much lower than the specific CK activities in skeletal muscle, heart and brain (2-37 U · [mg protein $]^{-1}$; [29,31-33]). We additionally observed that (i) the specific AdK activities in these samples were consistently higher than the specific CK activities (on average, > 10-fold), (ii) both activity measurements and cellulose polyacetate electrophoresis revealed similar specific AdK activities in the cytosolic and mitochondrial fractions (although from different AdK isoenzymes; data not shown), and (iii) mitochondrial respiration, in the presence of ATP, could be fully stimulated by AMP, but not by creatine (data not shown). This last observation favours the interpretation that in normal hepatocytes, CK isoenzymes are not expressed, and that the AdK isoenzyme system plays a function in high-energy phosphate buffering and transport, which is similar to the role of CK in brain, skeletal muscle and heart. Although histochemical data are missing, the results obtained here are most consistent with a localization of small amounts of BB-CK in sinusoidal endothelial cells [14].

Interestingly, we observed a strong induction of both BB$\mathrm{CK}$ and Mi-CK expression in two samples of primary HCC. Despite CK/AdK activity ratios in vitro of 1.4-2.6, the specific CK activities were still relatively low (0.21$0.36 \mathrm{U} \cdot[\mathrm{mg} \text { protein }]^{-1}$ ). Therefore, in the absence of histochemical data, it cannot be concluded with certainty whether the increased levels of CK are due to increased vascularization of the tumour (possibly associated with a higher proportion of CK-containing endothelial cells), or to induction of $\mathrm{CK}$ expression in the malignant cells.

Induction of CK expression has been observed previously in many types of tumours (see [2]) and may reflect an adaptation of the tumour tissue to the increased energetic demands. Evidence for induction of CK in liver tumours mostly comes from hepatoma cells grown in tissue culture $[34,35]$ or, indirectly, from increased amounts of circulating BB-CK and Mi-CK in the blood of patients with liver tumours [36]. On the other hand, analysis of the tumour tissue itself, both by classical biochemical methods and by microarray technology, provided inconsistent results. Some authors reported induction of CK expression in liver tumours ([37-39]; and, in part, [40]; M. Sakamoto and S. H. Yim, personal communication), others repression [41], and still others observed no statistically significant differences between normal and malignant liver tissue 

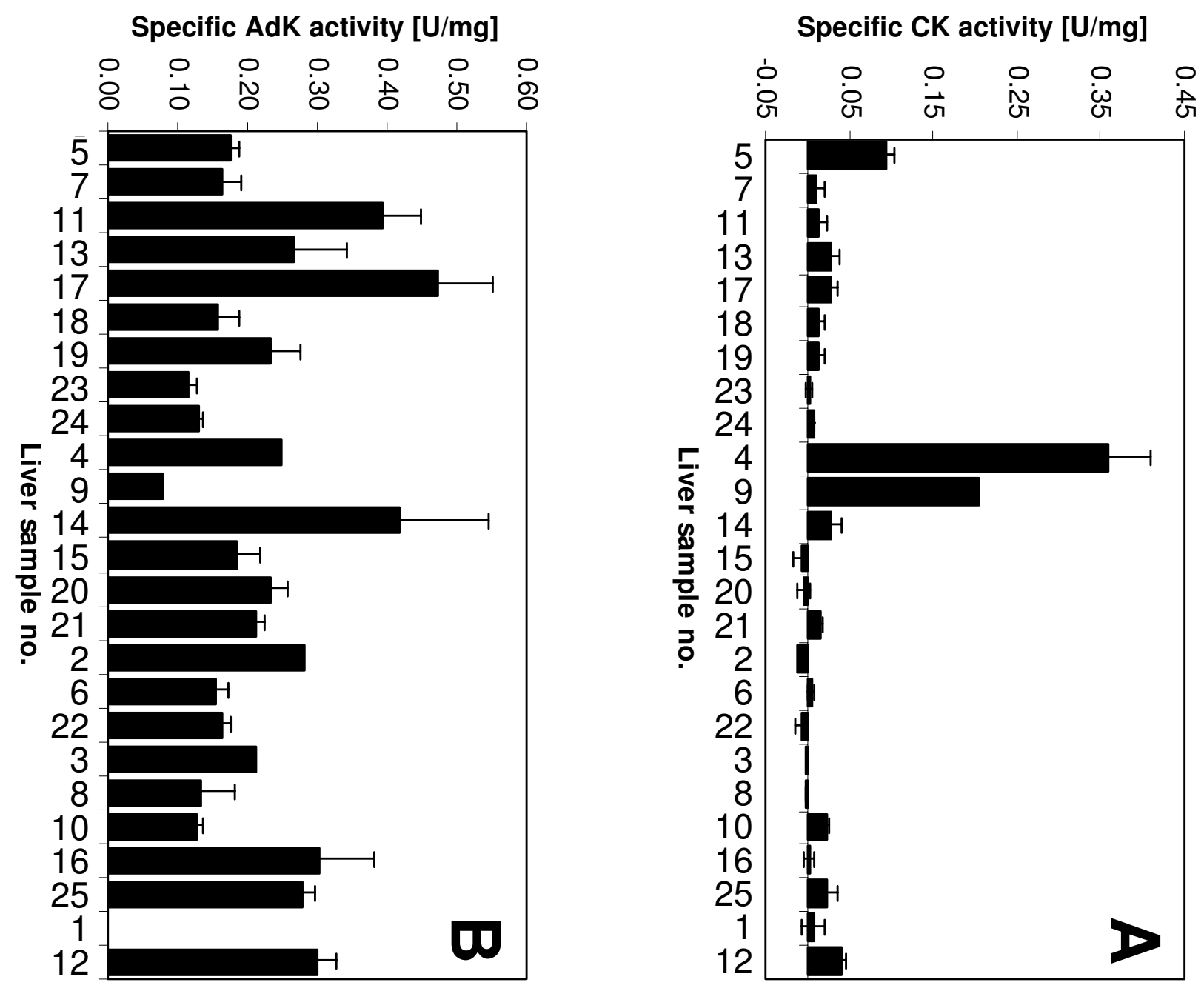

Figure I

CK and AdK activities in pathological and normal liver tissue. Specific CK (A) and AdK activities (B) in total homogenate fractions were determined as described under "Methods". The liver samples were classified into five groups: group I - cirrhotic liver tissue (nos. 5, 7, II, I3, 17-19, 23, 24); group 2 - neoplastic tissues (nos. 4, 9, 14, 15, 20, 2 I; 2 primary hepatocellular carcinomas [nos. 4 and 9]; 3 cholangiocellular carcinomas [nos. 14, 20 and 2I]; I liver metastasis of a malignant melanoma [no. 15]); group 3 - samples of necrotizing liver tissue due to acute or subacute organ rejection (nos. 2, 6, 22); group 4 - samples of macroscopically normal liver parenchymal tissue (nos. 3, 8, 10, 16, 25) surrounding focal liver pathologies ( 2 primary HCCs [nos. 4 and 9]; metastasis of malignant melanoma [no. I5]; vena hepatica occlusion [no. 24]); group 5 - samples originating from a normal rat liver (no. I2) and from a patient with steatosis hepatis (no. I). No AdK activity measurements are available for liver sample no. I.

$[11,30]$. This may be a reflection of the diverse clinicopathological and biological phenotypes of HCC, with different underlying molecular defects.
A key player in the picture might be the p53 tumour suppressor gene. Mutations in p53 are quite prevalent in HCC, especially in tumours with low cellular 


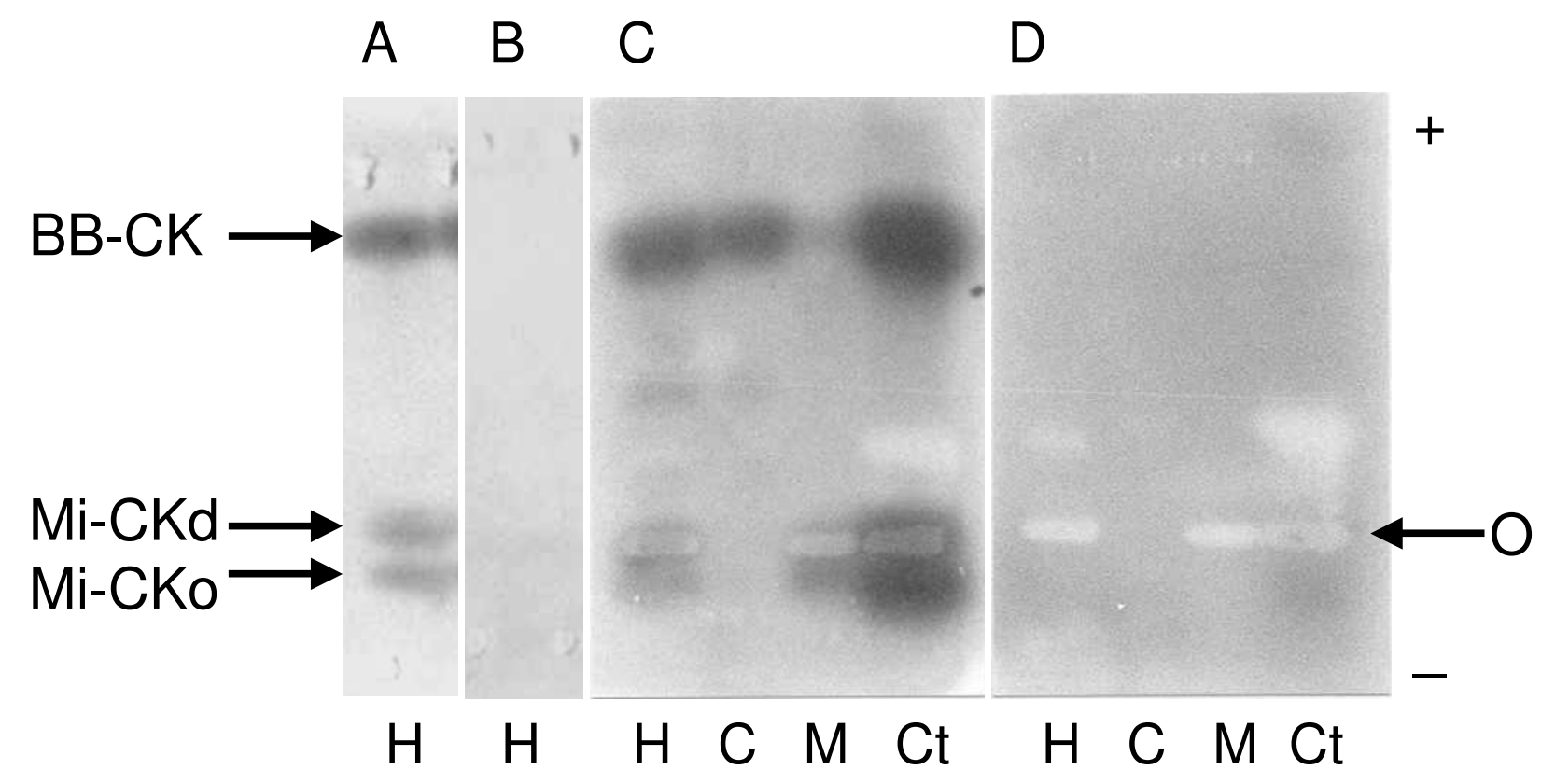

\section{Figure 2}

CK isoenzymes in HCC. Subcellular fractions of HCC liver samples no. 4 (A, B) and 9 (C, D) were analysed by cellulose polyacetate electrophoresis as described under "Methods". $H=$ total homogenate; $C=$ cytosolic fraction; $M=$ mitochondrial fraction; $\mathrm{Ct}=$ control containing BB-CK and Mi-CK; Mi-CKd = dimeric Mi-CK; Mi-CKo = octameric Mi-CK; O = place of sample application. The cellulose polyacetate strips were exposed to an overlay gel containing $\mathrm{PCr}(\mathrm{A}, \mathrm{C}=\mathrm{CK}$ activity staining), or lacking $\mathrm{PCr}(\mathrm{B}, \mathrm{D}=$ corresponding negative controls). Whereas Mi-CKd and Mi-CKo were well separated in (A), they were less so in $(C)$.

differentiation $[42,43]$. On the other hand, p53 was shown to control BB-CK expression: transrepression as observed for wild-type p53 is prevented by different mutations in the p53 gene [44]. Therefore, it is tempting to speculate that induction of BB-CK in HCCs is caused directly or indirectly by mutations in p53.

Expression of CK in HCC may have therapeutic implications, which is all the more important given (i) the limited responsiveness of HCC to currently available therapeutic approaches and, thus, (ii) the poor prognosis associated with this disease. $\mathrm{Cr}$ analogues (cyclocreatine and $\beta$-guanidinopropionic acid) and also $\mathrm{Cr}$ itself were previously shown to have antitumour activity, both in cell culture and in in vivo models $([45,46]$; see also [2]). The responsiveness of tumour cells to growth inhibition by cyclocreatine seems to be correlated with their specific CK activity; cell lines with a specific CK activity of $>0.10$ $\mathrm{U} \cdot(\mathrm{mg} \text { protein })^{-1}$ were generally sensitive to the drug. As for the liver, $\beta$-guanidinopropionic acid and creatine slowed the growth of AS30-D ascites tumour cells in culture (chemically induced rat hepatoma; [34]). Similarly, cyclocreatine revealed antitumour effects in a rat model of chemically induced hepatocarcinogenesis [47].

\section{Conclusion}

The present findings shed light on some old enigmas and open up fascinating avenues for future research. Our findings do not support significant expression of CK in normal liver and most liver pathologies, but rather indicate that many of the previous misconceptions in this field can be explained by interference from AdK isoenzymes. On the other hand, given the need for improved understanding of the molecular pathogenesis of HCC, and for improved therapies and cures, the induction of CK expression in HCC described here calls for a more in-depth analysis of the interplay between p53 mutations, HCC, CK expression, and the growth-inhibitory effects of cyclocreatine in HCC.

\section{List of abbreviations}

AdK, adenylate kinase; BB-CK, brain-type cytosolic CK isoenzyme; $\mathrm{CK}$, creatine kinase; $\mathrm{Cr}$, creatine; HCC, hepatocellular carcinoma; Mi-CK, mitochondrial CK; MM-CK, 
muscle-type cytosolic CK isoenzyme; PCr, phosphocreatine.

\section{Competing interests}

The authors declare that they have no competing interests.

\section{Authors' contributions}

GM and RM covered the medical part of this study. GM, FNG and MW performed the biochemical experiments. MW drafted the manuscript.

\section{Acknowledgements}

Ursula Walterscheid-Müller, Erich Gnaiger and all colleagues at the Department of General and Transplant Surgery of the University Hospital of Innsbruck are gratefully acknowledged for stimulating discussions and support, John Perkins for critical comments on the manuscript, and Michiie Sakamoto and Sunhee Yim for providing unpublished information. This work was supported by the Swiss National Science Foundation (fellowship No. 823A-037106), the Austrian Science Foundation (Lise Meitner fellowship No. M00 I98-MED), and the "Ciba-Geigy-Jubiläums-Stiftung".

\section{References}

I. Wallimann T, Wyss M, Brdiczka D, Nicolay K, Eppenberger HM: Intracellular compartmentation, structure and function of creatine kinase isoenzymes in tissues with high and fluctuating energy demands: the 'phosphocreatine circuit' for cellular energy homeostasis. Biochem J 1992, 28 I:2 I-40.

2. Wyss $M$, Kaddurah-Daouk $R$ : Creatine and creatinine metabolism. Physiol Rev 2000, 80:1 107-1213.

3. Cohen SM: Simultaneous ${ }^{13} \mathbf{C}$ and ${ }^{3}$ IP NMR studies of perfused rat liver. J Biol Chem 1983, 258:|4294-|4308.

4. Koretsky AP, Brosnan MJ, Chen L, Chen J, van Dyke T: NMR detection of creatine kinase expressed in liver of transgenic mice: determination of free ADP levels. Proc Natl Acad Sci USA 1990, 87:31|2-3116

5. Hatano E, Tanaka A, Iwata S, Satoh S, Kitai T, Tsunekawa S, Inomoto T, Shinohara H, Chance B, Yamaoka Y: Induction of endotoxin tolerance in transgenic mouse liver expressing creatine kinase. Hepatology 1996, 24:663-669.

6. Auricchio A, Zhou R, Wilson JM, Glickson JD: In vivo detection of gene expression in liver by ${ }^{3} 1 \mathrm{P}$ nuclear magnetic resonance spectroscopy employing creatine kinase as a marker gene. Proc Natl Acad Sci USA 2001, 98:5205-5210.

7. Masson S, Quistorff B: Kinetics of creatine uptake in the perfused mouse liver: a 31P-n.m.r. study of transgenic mice expressing creatine kinase $\left(\mathbf{C K}_{B B}\right)$ in the liver. Biochem J 1994 , 303:531-538.

8. Chazouilleres $O$, Vaubourdolle M, Robert A, Fourel V, Balladur P, Laribi A, Giboudeau J, Parc R, Poupon R, Hannoun L: Serum levels of endothelial injury markers creatine kinase-BB and soluble thrombomodulin during human liver transplantation. Liver 1996, I 6:237-240.

9. Wolf RFE, Haagsma EB, Kamman RL, Mooyaart EL, Sluiter WJ, Sloof $\mathrm{MJH}$ : Noninvasive metabolic assessment of human donor livers: prognostic value of $31 \mathrm{P}$-magnetic resonance spectroscopy for early graft function. Transplantation 1997, 64:|47-I52.

10. Askenasy N, Koretsky AP: Differential effects of creatine kinase isoenzymes and substrates on regeneration in livers of transgenic mice. Am J Physiol 1997, 273:C74I-C746.

II. Shatton JB, Morris HP, Weinhouse S: Creatine kinase activity and isozyme composition in normal tissues and neoplasms of rats and mice. Cancer Res 1979, 39:492-50I.

12. Goullé JP, Mechard D, Laine G, Jeanmet A, Cramer J, Maitrot B, Fondimare $A$, Gruchy $D$, Letac B: Répartition isozymique de la créatine kinase dans différents organes humains. Intérêt en pathologie humaine. Ann Biol Clin 1979, 37:303-307.

13. Wali FA, Makinde $V$ : Effects of pancuronium and vecuronium on creatine phosphokinase in rat isolated heart, liver, kidney and diaphragm. Gen Pharmacol 1991, 22:301-304.
14. Vaubourdolle M, Chazouilleres O, Poupon R, Ballet F, Braunwald J, Legendre C, Baudin B, Kirn A, Giboudeau J: Creatine kinase-BB: a marker of liver sinusoidal damage in ischemia-reperfusion. Hepatology 1993, I 7:423-428.

15. Kanemitsu F, Kawanishi I, Mizushima J: Characteristics of mitochondrial creatine kinases from normal human heart and liver tissues. Clin Chim Acta 1982, I I 9:307-3 I7.

16. Wu AHB, Herson VC, Bowers GN: Macro creatine kinase types I and 2: clinical significance in neonates and children as compared with adults. Clin Chem 1983, 29:20I-204.

17. Stein W, Bohner J, Renn W, Maulbetsch R: Macro creatine kinase type 2: results of a prospective study in hospitalized patients. Clin Chem 1985, 3 I: 1959-1964.

18. Castaldo G, Salvatore F, Sacchetti L: Serum type-2 macro-creatine kinase isoenzyme is not a useful marker of severe liver diseases or neoplasia. Clin Biochem 1990, 23:523-527.

19. Keshgegian AA, Marchant BL: Cathodal bands in electrophoretograms of creatine kinase isoenzymes in serum collected after cardiac surgery: a poor prognostic sign. Clin Chem 1983, 29: $1727-1730$.

20. Schmidt E, Klauke R, Schmidt FW: Interference of adenylate kinase (AK) with creatine kinase (CK) determination in sera of patients with acute liver cell damage. Fresenius $Z$ Anal Chem 1988, 330:365

21. Murthy VV: Adenylate kinase mimics creatine kinase-MM isoenzyme in a CK isoenzyme electrophoresis assay. J Clin Lab Anal 1994, 8: |40-143.

22. Malnick SDH, Bass DD, Kaye AM: Creatine kinase BB: a response marker in liver and other organs. Hepatology 1994, 19:261.

23. Brosnan MJ, Chen L, Wheeler CE, van Dyke TA, Koretsky AP: Phosphocreatine protects ATP from a fructose load in transgenic mouse liver expressing creatine kinase. Am J Physiol 1991, 260:CII9I-CI200.

24. Miller K, Halow J, Koretsky AP: Phosphocreatine protects transgenic mouse liver expressing creatine kinase from hypoxia and ischemia. Am J Physiol I 993, 265:CI544-CI55I.

25. Satoh S, Tanaka A, Hatano E, Inomoto T, Iwata S, Kitai T, Shinohara $H$, Tsunekawa S, Chance B, Yamaoka Y: Energy metabolism and regeneration in transgenic mouse liver expressing creatine kinase after major hepatectomy. Gastroenterology 1996, I | 0: | | 66- I I74

26. Kanazawa A, Tanaka A, Iwata S, Satoh S, Hatano E, Shinohara H, Kitai T, Tsunekawa S, Ikai I, Yamamoto M, Takahashi R, Chance B, Yamaoka $Y$ : The beneficial effect of phosphocreatine accumulation in the creatine kinase transgenic mouse liver in endotoxin-induced hepatic cell death. J Surg Res 1998, 80:229-235.

27. Bradford MM: A rapid and sensitive method for the quantitation of microgram quantities of protein utilizing the principle of protein dye binding. Anal Biochem 1976, 72:248-254

28. Wyss M, Schlegel J, James P, Eppenberger HM, Wallimann T: Mitochondrial creatine kinase from chicken brain. Purification, biophysical characterization, and generation of heterodimeric and heterooctameric molecules with subunits of other creatine kinase isoenzymes. J Biol Chem 1990, 265: $15900-15908$.

29. Wyss M, Wallimann T, Köhrle J: Selective labelling and inactivation of creatine kinase isoenzymes by the thyroid hormone derivative N-bromoacetyl-3,3',5-tri-iodo-L-thyronine. Biochem J 1993, 29 I:463-472.

30. Joseph J, Cardesa A, Carreras J: Creatine kinase activity and isoenzymes in lung, colon and liver carcinomas. $\mathrm{Br} J$ Cancer 1997, 76:600-605.

31. Ishida Y, Wyss M, Hemmer W, Wallimann T: Identification of creatine kinase isoenzymes in the guinea-pig. Presence of mitochondrial creatine kinase in smooth muscle. FEBS Lett 1991, 283:37-43.

32. Manos $\mathrm{P}$, Bryan GK, Edmond J: Creatine kinase activity in postnatal rat brain development and in cultured neurons, astrocytes, and oligodendrocytes. J Neurochem 1991, 56:2101-2107.

33. Nascimben L, Ingwall JS, Pauletto P, Friedrich J, Gwathmey JK, Saks V, Pessina AC, Allen PD: Creatine kinase system in failing and nonfailing human myocardium. Circulation 1996, 94: I894-1901.

34. Baggetto LG, Clottes E, Vial C: Low mitochondrial proton leak due to high membrane cholesterol content and cytosolic creatine kinase as two features of the deviant bioenergetics 
of Ehrlich and AS30-D tumor cells. Cancer Res 1992, 52:4935-494I.

35. Ronen SM, Volk A, Mispelter J: Comparative NMR study of a differentiated rat hepatoma and its dedifferentiated subclone cultured as spheroids and as implanted tumors. NMR Biomed 1994, 7:278-286.

36. Kanemitsu F, Kawanishi I, Mizushima J, Okigaki T: Mitochondrial creatine kinase as a tumor-associated marker. Clin Chim Acta 1984, 138: 175-183.

37. Salyamon LS, Ashmarin IP, Ostrezova IB, Lyzlova SN, Pluzhnikova GF, Vas'kina LV: The analysis of tumor transformation of tissues. II. Biochemical dedifferentiation of tissue during carcinogenesis (changes of creatine kinase and alkaline phosphatase activity taken as an example). Tsitologiya 1970, 12:102-II0.

38. Tackels-Horne D, Goodman MD, Williams AJ, Wilson DJ, Eskandari T, Vogt LM, Boland JF, Scherf U, Vockley JG: Identification of differentially expressed genes in hepatocellular carcinoma and metastatic liver tumors by oligonucleotide expression profiling. Cancer 200I, 92:395-405.

39. Yim SH, Ward JM, Dragan Y, Yamada A, Scacheri PC, Kimura S, Gonzalez F): Microarray analysis using amplified mRNA from laser capture microdissection of microscopic hepatocellular precancerous lesions and frozen hepatocellular carcinomas reveals unique and consistent gene expression profiles. Toxicol Pathol 2003, 31:295-303.

40. Chen X, Cheung ST, So S, Fan ST, Barry C, Higgins J, Lai K-M, Ji J, Dudoit S, Ng IOL, van de Rijn M, Botstein D, Brown PO: Gene expression patterns in human liver cancers. Mol Biol Cell 2002, I 3:1929-1939.

4I. Xu X-R, Huang J, Xu Z-G, Qian B-Z, Zhu Z-D, Yan Q, Cai T, Zhang $X$, Xiao H-S, Ou J, Liu F, Huang Q-H, Cheng Z-H, Li N-G, Du J-J, Hu W, Shen K-T, Lu G, Fu G, Zhong M, Xu S-H, Gu W-Y, Huang W, Zhao X-T, Hu G-X, Gu J-R, Chen Z, Han Z-G: Insight into hepatocellular carcinogenesis at transcriptome level by comparing gene expression profiles of hepatocellular carcinoma with those of corresponding noncancerous liver. Proc Natl Acad Sci USA 200I, 98:I5089-I5094.

42. Ng IOL, Chung LP, Tsang SWY, Lam CL, Lai ECS, Fan ST, Ng M: p53 gene mutation spectrum in hepatocellular carcinomas in Hong Kong Chinese. Oncogene 1994, 9:985-990.

43. Jackson PE, Qian G-S, Friesen MD, Zhu Y-R, Lu P, Wang J-B, Wu Y, Kensler TW, Vogelstein B, Groopman JD: Specific p53 mutations detected in plasma and tumors of hepatocellular carcinoma patients by electrospray ionization mass spectrometry. Cancer Res 2001, 61:33-35.

44. Zhao J, Schmieg FI, Simmons DT, Molloy GR: Mouse 553 represses the rat brain creatine kinase gene but activates the rat muscle creatine kinase gene. Mol Cell Biol 1994, I 4:8483-8492.

45. Lillie JW, O'Keefe M, Valinski H, Hamlin HA, Varban ML, KaddurahDaouk R: Cyclocreatine (I-carboxymethyl-2-iminoimidazolidine) inhibits growth of a broad spectrum of cancer cells derived from solid tumors. Cancer Res 1993, 53:3172-3178.

46. Martin KJ, Winslow ER, O'Keefe M, Khandekar VS, Hamlin A, Lillie JW, Kaddurah-Daouk R: Specific targeting of tumor cells by the creatine analog cyclocreatine. Int J Oncol 1996, 9:993-999.

47. Jeong K-S, Park S-J, Lee C-S, Kim T-W, Kim S-H, Ryu S-Y, Williams $\mathrm{BH}$, Veech RL, Lee Y-S: Effects of cyclocreatine in rat hepatocarcinogenesis model. Anticancer Res 2000, 20:1627-1634.

\section{Pre-publication history}

The pre-publication history for this paper can be accessed here:

http://www.biomedcentral.com/1471-230X/5/9/prepub

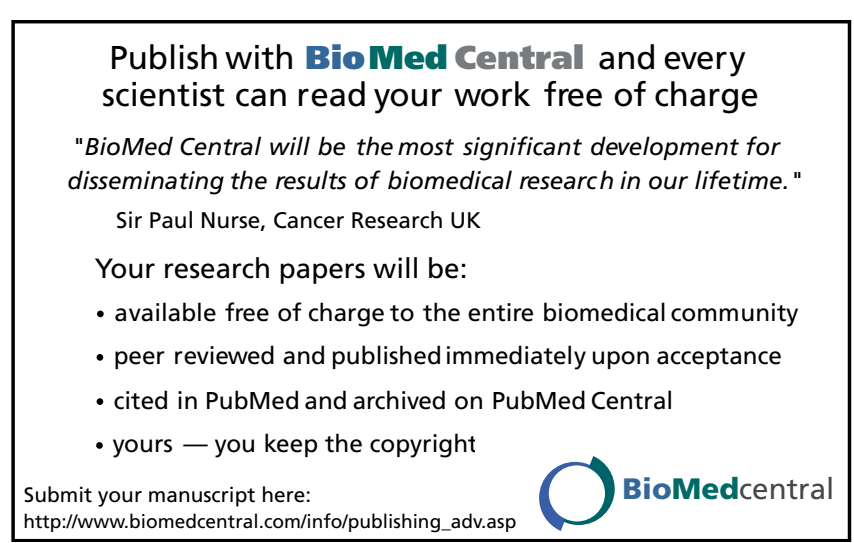

